\title{
Skin vascular malformations and recurrent melena which refers to a nevus syndrome
}

\author{
Hemanta K Nayak, Nishant Raizada, Nitin Sinha, Mradul Kumar Daga
}

Department of Medicine Maulana Azad Medical College, New Delhi, India

\section{Correspondence to} Dr Hemanta K Nayak, drhemantnayak@gmail.com

\section{DESCRIPTION}

A 14-year-old North Indian boy presented with a one-year history of multiple hospitalisation anamnesis for recurrent melaena and anaemia. He had received iron supplementation and whole-blood transfusions of more than 10 units for the last 1 year. On physical examination, we observed multiple dark blue, soft, lobulated lesions $(5-20 \mathrm{~mm})$ on his palm, sole and extremities which were present for the last 2 years (figure 1). With the application of direct pressure the contained blood emptied leaving behind a wrinkled sac. Doppler ultrasonography of the abovementioned skin lesions suggested multiple dilated venous lesions filled with blood without any arteriovenous communication. Mucous surfaces of the patient were free of bleb-like lesions and were severely pale. His haemoglobin level was $7 \mathrm{~g} / \mathrm{dl}$, with hypochromic microcytosis indicating iron deficiency. Occult blood analysis of the stool was positive on many occasions. Oesophagogastroduodenoscopy revealed bluish venous malformations in stomach and proximal duodenum. Colonoscopy revealed multiple papular venous malformations of approximately 1$2 \mathrm{~cm}$ in size located at the distal, ascending colon and transverse colon (figure 2). In order to search for additional lesions, we carried out double balloon enteroscopy and identified multiple venous malformations in the jejunum and ileum. He was treated with multiple sessions of endoscopic sclerotheraphy of the

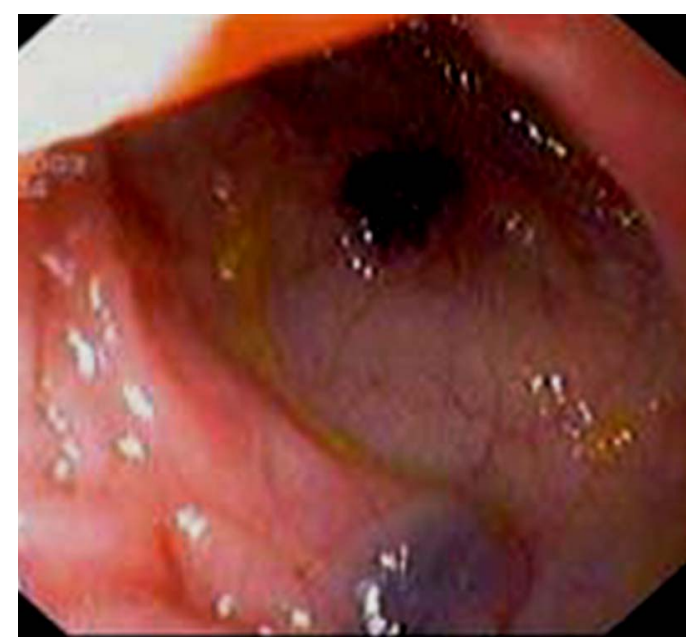

Figure 2 Colonoscopy revealed bluish venous malformation in ascending colon.

gastrointestinal (GI) venous lesions in addition to the blood transfusion and iron supplementation. Our patient's case draws attention to a rare vascular anomaly syndrome predominately involving the skin and whole GI tract. This patient was a case of blue rubber bleb nevus syndrome who was successfully treated with multiple endoscopic therapeutic sessions, transfusion and haematinics supplementation. ${ }^{12}$
To cite: Nayak HK, Raizada N, Sinha N, et al. BMJ Case Rep Published online: [please include Day Month Year] doi:10.1136/ bcr-2013-009064

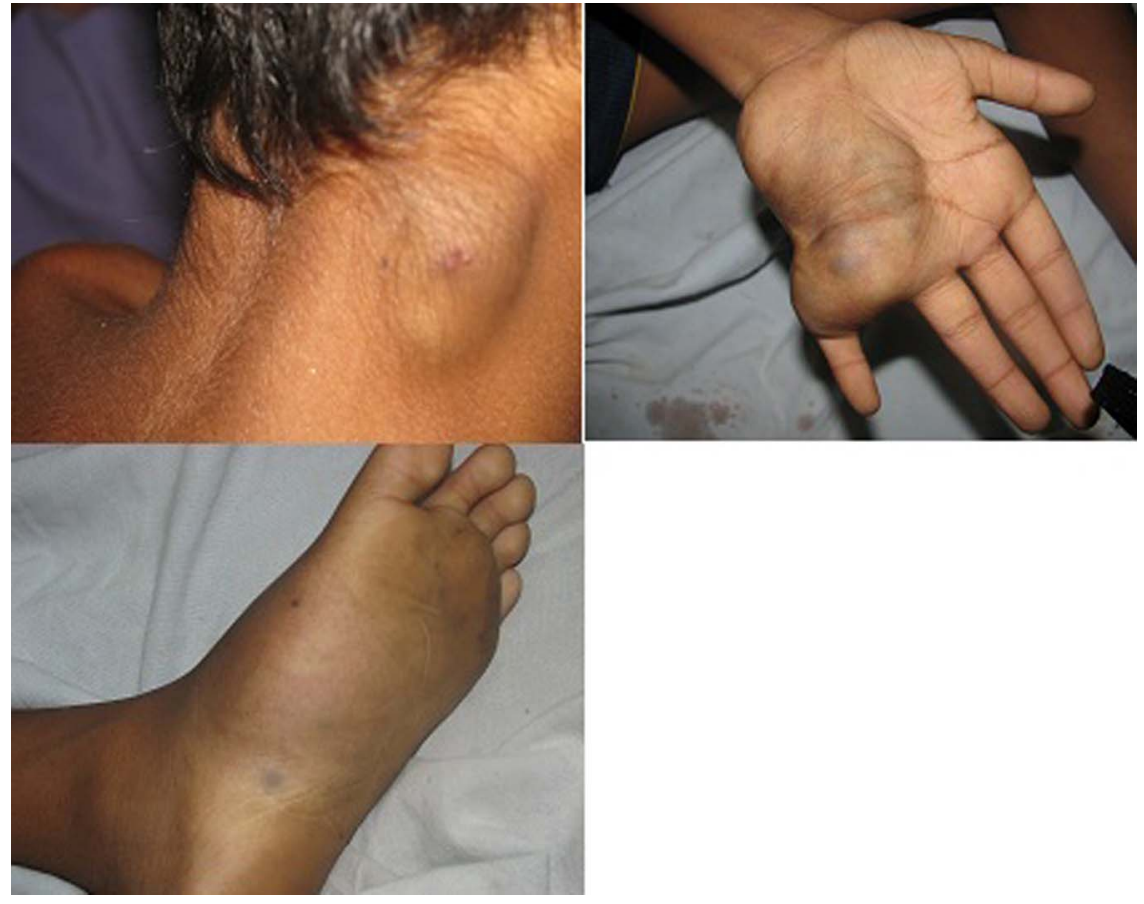

Figure 1 Multiple dark blue, soft, lobulated lesions $(5-20 \mathrm{~mm})$ on his palm, sole and back of the neck. 


\section{Learning points}

- Patients with recurrent melaena and severe anaemia with simultaneous involvement of skin vascular malformations need visualisation of the whole gastrointestinal (GI) tract by combination of modalities such as oesophagogastroduodenoscopy, colonoscopy and enteroscopy in order to investigate the extent of GI tract involvement by vascular malformations and eradication of vascular lesions either by endoscopic therapy or by other modalities and prevent the patient from future recurrent $\mathrm{GI}$ blood loss and severe anaemia.

- The skin lesions of Blue rubber bleb nevus syndrome (BRBNS) are usually small, multiple, measuring less than $1-2 \mathrm{~cm}$, and blue to purple in colour. Although skin is most commonly involved in BRBNS, the GI lesions may be clinically more relevant.

- Regular follow up with hemoglobin ans stool for occult blood should be done in these patients.
Contributors HKN, NR and NKS were involved in patients management preparation of manuscript. MKD supervised the patient management and editing of the manuscript.

Competing interests None.

Patient consent Obtained.

Provenance and peer review Not commissioned; externally peer reviewed.

\section{REFERENCES}

1 Dobru D, Seuchea N, Dorin M, et al. Blue rubber bleb nevus sydrome: case report and literature review. Rom J Gastroenterol 2004;13:237-40.

2 Gallo SH, McClave SA. Blue rubber bleb nevus syndrome: gastrointestinal involvement and its endoscopic presentation. Gastrointest Endosc 1992;38:72-6.

Copyright 2013 BMJ Publishing Group. All rights reserved. For permission to reuse any of this content visit http://group.bmj.com/group/rights-licensing/permissions.

BMJ Case Report Fellows may re-use this article for personal use and teaching without any further permission.

Become a Fellow of BMJ Case Reports today and you can:

- Submit as many cases as you like

- Enjoy fast sympathetic peer review and rapid publication of accepted articles

- Access all the published articles

- Re-use any of the published material for personal use and teaching without further permission

For information on Institutional Fellowships contact consortiasales@bmjgroup.com

Visit casereports.bmj.com for more articles like this and to become a Fellow 